\title{
Intensive management reduces butterfly diversity over time in urban green spaces
}

\author{
Guillermo Aguilera ${ }^{1}$ (D) $\cdot$ Johan Ekroos $^{2} \cdot$ Anna S. Persson $^{2} \cdot$ Lars B. Pettersson $^{3} \cdot$ Erik Öckinger $^{1}$
}

Published online: 7 November 2018

(C) The Author(s) 2018

\begin{abstract}
Loss and fragmentation of semi-natural grasslands have had negative consequences for grassland biodiversity, such as butterflies. Urban parks and other urban green spaces have so far largely been overlooked as suitable butterfly habitats, although they could potentially sustain diverse butterfly populations over time. We analysed the temporal change in butterfly species assemblages in urban green spaces in the city of Malmö, Southern Sweden. We studied changes in species richness and abundance of butterflies between 2006 and 2015 in 20 public urban green spaces, characterized by different management regimes. We sampled butterflies in traditional parks with intense grass cutting regimes, in semi-natural grasslands mowed only a few times per year, and in unmanaged or irregularly managed ruderal sites. We found a slight increase in the total number of butterfly species in the study area, but a general decline in local species numbers in urban green spaces. Traditional urban parks had the greatest loss of species over time, and altogether the lowest number of species. In contrast, semi-natural parks and ruderal sites had higher numbers of butterfly species and also lost fewer species over time. Our study shows that intensive management strategies in urban green spaces have a negative impact on butterfly assemblages over time. We suggest that less intensive management strategies can be used to create high-quality areas for flower-visiting insects in urban green spaces, possibly in combination with planting larval host plant species, depending on the park type and design.
\end{abstract}

Keywords Lepidoptera $\cdot$ Species richness $\cdot$ Temporal decline $\cdot$ Urban green space $\cdot$ Park management

\section{Introduction}

Landscape fragmentation and habitat transformation by rapid agricultural intensification are among the main causes for the loss of biodiverse habitats, such as semi-natural grasslands (Green 1990; Luoto et al. 2003). Studies on grassland species have revealed marked declines and local extinctions amongst flower-visiting insects (Nilsson et al. 2013; Potts et al. 2010;

Electronic supplementary material The online version of this article (https://doi.org/10.1007/s11252-018-0818-y) contains supplementary material, which is available to authorized users.

Guillermo Aguilera

guillermo.aguilera.nunez@slu.se

Johan Ekroos

Johan.ekroos@cec.lu.se

Anna S. Persson

Anna.persson@cec.lu.se

Lars B. Pettersson

Lars.pettersson@biol.lu.se
Van Swaay et al. 2016), in particular concerning species with high habitat specificity (Kuussaari et al. 2007). Urbanization has emerged as another main driver of habitat loss and fragmentation of natural and semi-natural habitats (Parris 2016). Local changes relating to loss of habitat quantity or quality are among the most important drivers of biodiversity loss in urban contexts (Beninde et al. 2015; Merckx et al. 2018). In addition, disturbance and management intensity typically

Erik Öckinger

Erik.ockinger@slu.se

1 Department of Ecology, Swedish University of Agricultural Sciences, Box 7044, SE-75007 Uppsala, Sweden

2 Centre for Environmental and Climate Research, Lund University, Lund, Sweden

3 Biodiversity Unit, Department of Biology, Lund University, Lund, Sweden 
increases with urbanization, leading to further negative effects on urban biodiversity (Beninde et al. 2015; McKinney 2008; Aronson et al. 2017).

Semi-natural habitats in urban settings have gained increased attention in biodiversity research in recent years (e.g. Ferenc et al. 2014; Gardiner et al. 2013; Gunnarsson and Federsel 2014; Hill et al. 2017; Kaluza et al. 2016; Venn et al. 2013). Although many urban areas may appear to be poor habitats, urban animal and plant communities can be equally biodiverse compared to those in surrounding landscapes (Baldock et al. 2015; Hall et al. 2017; McKinney 2006; Turrini and Knop 2015), especially when the surroundings are dominated by intensively managed agricultural land. Urban landscapes offer a variety of green spaces, potentially providing habitats with diverse management regimes that could benefit species associated with semi-natural grasslands (Blair and Launer 1997). Urban green spaces range from heavily managed traditional public parks containing high proportions of exotic species, to irregularly managed semi-natural and ruderal patches allowing establishment of diverse plant communities.

Amongst grassland species, butterfly assemblages can be diverse in semi-natural grasslands in peri-urban areas (Haaland 2017), and some species are abundant in heavily transformed urban habitats, including parks and a variety of unmanaged green spaces (Bergerot et al. 2012; Öckinger et al. 2009). Patch area, corridors, habitat management, and vegetation structure contribute to maintaining high biodiversity in cities (Beninde et al. 2015), and research has shown that low intensity local management practices and decreasing habitat isolation benefit urban butterfly diversity (Chong et al. 2014; Lizée et al. 2011; Öckinger et al. 2009).

Given the close association between grasslands and butterfly diversity, surprisingly little attention has been given to butterflies in urban grassland habitats. In particular, there is virtually no knowledge about how butterflies respond to different management regimes over time in urban settings. Based on data collected in 2006, Öckinger et al. (2009) showed that urban sites in general had slightly lower (9.6\%) butterfly diversity compared with surrounding semi-natural grasslands, and amongst urban sites, unmanaged ruderal sites had a higher butterfly diversity compared to intensively managed traditional urban parks. However, the fast urban development of Malmö in the last decade may have altered the habitat and landscape conditions to an extent where butterfly diversity cannot longer remain at previous levels (Moström and Svanström 2015). Therefore, this study system offers a unique opportunity to analyse temporal changes in butterfly assemblages in a rapidly developing urban region. In addition, because their ecology is well-known, butterflies are frequently used as biodiversity indicators (Thomas 2005; Van Swaay et al. 2016). Changes in butterfly assemblages may therefore reflect more general changes in urban grassland biodiversity.
In this study we replicated the survey by Öckinger et al. (2009) to assess the magnitude of change in butterfly communities between 2006 and 2015 in urban green spaces in Malmö. We revisited the sites and surveyed butterflies using as similar methodologies as possible to assess which management practices and habitat characteristics support high butterfly diversity over time. Our ultimate aim was to investigate whether management intensity of urban green spaces has an effect on butterfly diversity and on extinction and colonisation processes over time. Based on previous literature, we expected to find lower butterfly diversity and stronger declines over time in intensively-managed sites. Traditional parks, being urban green spaces designed mainly for public leisure, are characterised by intensive grass cutting regimes and introduction of non-native ornamental plants, resulting in less suitable habitats for grassland butterflies.

\section{Methods}

\section{Study area}

Malmö is the third-largest city in Sweden. With a population of around 300,000 residents, Malmö is the commercial centre of southern Sweden and has historically been an industrial city. During the last few decades, industrial land use has decreased whilst urban land cover in general has increased because of increased demand of new residential areas. As an example of the fast development of the city, the population grew by approximately 50,000 inhabitants between the study years (2006-2015). The city of Malmö is predominantly surrounded by homogeneous and intensively managed agricultural land (Öckinger et al. 2009; Persson et al. 2010) except in the west, where it is bordered by the sea (Öresund). The urban area of Malmö consists of ca $45 \%$ green space cover, including parks, informal green spaces and vegetation in residential areas (SCB 2015).

\section{Selection of study sites}

We initially selected the same 20 sites as in Öckinger et al. (2009) (Fig. 1). Sites were categorised as ruderal, semi-natural, or traditional parks, based on the original habitat classification of the sites made in 2006 (Öckinger et al. 2009). Ruderal sites were non-managed or irregularly managed, characterised by early successional vegetation. They were mostly abandoned spaces and other green areas within the industrial part of the city, with negligible recreational use by citizens. Semi-natural sites were parks with tall grass mowed once or twice per year; and traditional parks were city parks with short mowed grass, planted ornamental flower beds, and trees. The area of one ruderal site sampled in 2006 was reduced by approximately $50 \%$, but it was included in this study 


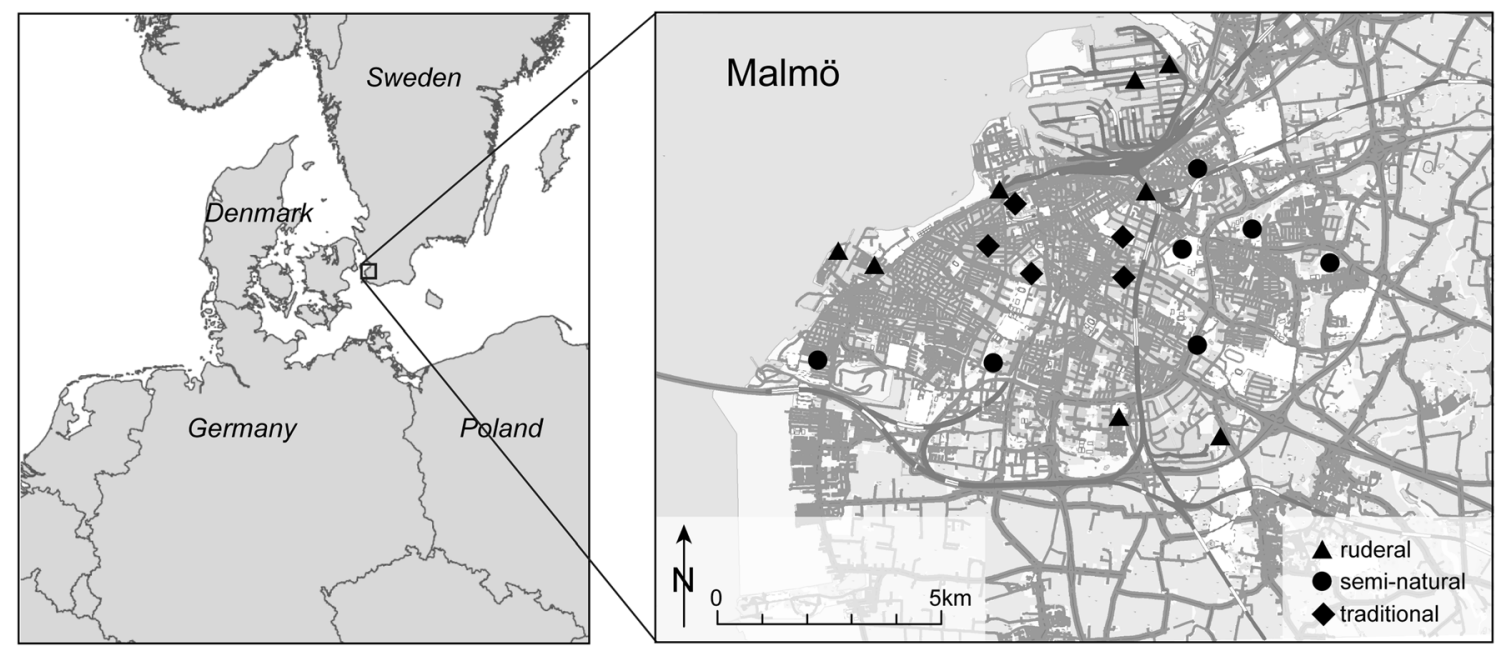

Fig. 1 Study sites distribution classified by management in Malmö, region of Skåne (Southern Sweden)

since the remaining part was unaltered. Land-use in another ruderal site sampled in 2006 was completely transformed and was therefore replaced with another site with similar habitat characteristics as the original site. Finally, one site classified as semi-natural in 2006 was classified as a traditional park in 2015 , since it did not correspond to the definitions of seminatural areas based on its grass-cutting regime, vegetation height, and recreational use. We did not include the two latter sites when comparing temporal changes in butterfly communities. Hence, our final sample size was based on 5 traditional parks, 7 semi-natural parks and 8 ruderal areas. The area of the sites ranged between 0.14 and 3.9 ha $(1.22 \pm 0.26$ mean $\pm \mathrm{SE}$; traditional $=0.40 \pm 0.14$, semi-natural $=0.96 \pm 0.15$, and ruderal $=1.95 \pm 0.54$ ).

\section{Butterfly survey}

In each study, site butterflies and burnet moths were surveyed with standardized transect counts (Pollard and Yates 1993). During the first visit to each site, transects were marked with a GPS. Transect length was proportional to the area of the site, with an approximate length of $150 \mathrm{~m}$ per hectare, following the methodology used in the previous study (Öckinger et al. 2009).

During the transect counts, every butterfly observed within $5 \mathrm{~m}$ ahead and $2.5 \mathrm{~m}$ on either side of the surveyor was noted. Five visits (between the 5th of June and the 2nd of August) were made to each site in order to cover the activity periods of different butterfly species. We sampled sites of all habitat types during the same day to minimise sampling bias due to e.g. weather conditions. Surveys were made only during favourable weather (Wikström et al. 2009). Because May 2015 was cold and rainy, the surveys started a few weeks later compared to Öckinger et al. (2009).

\section{Vegetation measurements}

We measured flower abundance and vegetation height as indicators of habitat quality. Vegetation height was measured using a grass ruler (Ekstam and Forshed 1996). The ruler was placed vertically on the ground and the vegetation height was defined visually from a distance of $5 \mathrm{~m}$ as the point where the vegetation covered $50 \%$ or more of the ruler surface. Flower abundance was measured with a $50 \times 50 \mathrm{~cm}$ plot divided into 25 identical squares of $10 \times 10 \mathrm{~cm}$. The number of squares containing at least one flower of any plant species was noted, i.e. a flower abundance of 25 was the maximum score for each plot.

Both vegetation height and flower abundance were measured once in each site between June 24th and the July 15th (before and during the 4th sampling), with ten measurements evenly distributed along each transect. Transects were placed to proportionally represent the different vegetation types found in each site.

\section{Landscape variables}

Apart from the two variables describing vegetation characteristics, additional habitat and landscape variables were calculated using QGIS 2.18.4 and ArcGIS 10.3.1. Landscape variables were calculated based on a $2 \mathrm{~km}$ radius circumference buffer, which was created for every study site. The proportions of water bodies and built-up areas for every site were calculated within these $2 \mathrm{~km}$ buffers based on GIS-layers provided by Malmö municipality, Streets and Parks Department. The proportion of green spaces was estimated using QGIS and a Google satellite image (2003-2008). The minimum distance from each study site to the edge of the city was measured in QGIS to estimate distance between the focal sites and 
presumed source populations in the semi-natural habitats in the peri-urban landscape as suggested by Öckinger et al. (2009).

\section{Statistical analyses}

All analyses were done in R 2.14.0 (R Core Team 2016). Using data from 2015 we initially tested if the three management types differed in vegetation height, distance to the edge of the city and proportion of green spaces in the surrounding landscapes using ANOVA. Based on these initial analyses, we found significant differences in all three variables between management types (see results). In order to avoid collinearity, we first dropped these variables from further analyses of habitat-specific differences in butterfly assemblages, and subsequently evaluated possibly confounding effects caused by habitat area, distance to the edge of the city and proportion of green spaces in the surrounding landscapes in subsequent analyses (see below).

We first analysed differences in total butterfly species richness between management types using ANOVA, including management type as the single explanatory factor. Here, total species richness was calculated as the aggregated number of butterfly species observed per site in 2015. As we found no correlation between total number of butterfly species and site area $(r=0.16)$, we consider that effects of local management will have stronger effects than the urban green space area per se. We thereafter compared butterfly species richness observed per site in 2015 with the data collected during 2006 by Öckinger et al. (2009), using a paired t-test. Because the number of butterfly individuals in 2015 were considerably lower compared with 2006 (see the "Results" section), possibly because of weather conditions (Pollard and Yates 1993; Wikström et al. 2009) and slight differences in sampling effort (Öckinger et al. 2009), we additionally compared rarefied species richness using the vegan $\mathrm{R}$ package version $2.4-5$ (Oksanen et al. 2017) between years using site as random factor to ensure comparability of species richness between datasets. Following Clough et al. (2014), sites with fewer than five individuals were excluded from the datasets of both years. Analyses on rarefied species richness were thus based on a subset of 32 sites (16 for each year, including only sites that were identical in terms of area and management in both samplings).

In addition, we calculated the proportional loss or gain in number of species per site over time as a ratio (number of species observed per site in 2015 divided by the number of species observed per site in 2006) in order to standardize species loss and gain on a relative scale. We analysed the proportional loss and gain of butterfly species over time in relation to management types using ANOVAs.

Finally, differences in species colonisations and extinctions per site were calculated for the period between the years 2006 and 2015 for each site, operationally defining those species that were found in 2006 but not in 2015 as extinctions, and species found in 2015 but not in 2006 as colonisations (See Table 1 in Online Resources).

To examine the relative strength of confounding effects between habitat type, patch size, and landscape variables on colonisation and extinction per management type, we first used three liner mixed-effects models using the nlme $\mathrm{R}$ package version 3.1-128 (Pinheiro et al. 2016). In these models we included (i) patch size, (ii) distance to the edge, and (iii) proportion of green urban spaces as fixed terms, while keeping habitat type as a random variable in each model. Because all three fixed term landscape variables were non-significant (see results), differences in colonisations and extinctions per management type were analysed using ANOVAs. We thereafter tested whether vegetation height, distance to the edge of the city or proportion of green urban spaces within two kilometre radius buffers explained patterns in colonisations or extinctions per site between sites with similar characteristics (vegetation height and distance to the edge regarding ruderal and semi-natural sites, and proportion of green spaces regarding ruderal and traditional sites), using linear mixed-effects models. We included habitat type as a random factor in these models. We verified model assumptions (normality of model residuals and variance homogeneity) by visually inspecting residual plots.

\section{Results}

\section{Differences in landscape and local characteristics between management types}

The three urban green space types differed in vegetation height $\left(\mathrm{F}_{1,17}=16.25, P<0.001\right)$, distance to the edge of the city $\left(\mathrm{F}_{1,17}=4.43, P=0.028\right)$, and proportion of green spaces in the surrounding landscapes $\left(\mathrm{F}_{1,17}=6.16, P=0.010\right)$. Traditional parks had significantly shorter vegetation height than semi-natural and ruderal sites (post hoc adjusted $p$ values: semi-natural versus ruderal $P=0.717$, traditional versus ruderal $P<0.001$, traditional versus semi-natural $P<0.001)$ and were situated further away from the city edge compared to semi-natural sites (post hoc adjusted $P$-values: semi-natural - ruderal $P=0.650$, traditional - ruderal $P=$ 0.101 , traditional - semi-natural $P=0.024)$. Semi-natural sites had a greater proportion of other green spaces in the surrounding landscapes, compared to both ruderal sites and traditional parks (post hoc adjusted $p$-values: semi-natural - ruderal $P=$ 0.019 , traditional - ruderal $P=0.960$, traditional - seminatural $P=0.022$ ). 


\section{Butterfly diversity}

A total of 2469 individuals of 17 different species were found in 2015 (See Table 2 in Online Resources), compared to the 3922 individuals of 15 different species recorded in the previous study by Öckinger et al. (2009) for the 19 sites surveyed in both studies. In 2015 Maniola jurtina was the most abundant species followed by Zygaena filipendulae, Aphantopus hyperantus, Pieris rapae, and Polyommatus icarus, which together constituted more than $90 \%$ of the total individuals recorded. Compared with 2006, three new species were observed in 2015 (Celastrina argiolus, Satyrium w-album, and Cupido minimus), whereas one was no longer observed (Gonepteryx rhamni). Aphantopus hyperantus, Thymelicus lineola, Aricia agestis, and Pieris brassicae were more widespread across all sites in 2015, increasing their occurrence (number of sites) by $200 \%, 250 \%, 500 \%$ and a $200 \%$ respectively; and two species, Maniola jurtina and Aphantopus hyperantus, were 25\% and 197\% more abundant in 2015 compared with 2006 , respectively.

In 2015, traditional parks had the lowest number of observed species while ruderal areas were the most diverse sites (Table 1). The three management types differed significantly in species numbers $\left(\mathrm{F}_{2}=33.81, P<0.001\right.$; Table 1$)$. Although the total number of observed species across all sites increased from 15 to 17 , the total number of species per site decreased significantly between 2006 and 2015 ( $8.0 \pm 2.7$ in 2006 versus $6.1 \pm 3.2$ in 2015), i.e. an average decline of almost two species per site $\left(\mathrm{t}_{1}, 18=2.2, P=0.041\right)$. In a similar way, the rarefied species richness declined significantly from 2006 $(2.9 \pm 0.4)$ to $2015(2.3 \pm 0.6)\left(\mathrm{t}_{15}=-3.11, P=0.007\right.$; Fig. 2$)$.

\section{Proportional change in species richness over time}

In traditional parks the relative loss in butterfly species between 2006 and 2015 was higher compared to ruderal and semi-natural parks, whereas the latter two categories did not differ from each other $\left(\mathrm{F}_{2,16}=10.58, P=0.001\right.$; post hoc adjusted $p$-values: semi-natural versus ruderal $P=0.897$, traditional versus ruderal $P=0.002$, traditional versus semi-natural $P=0.004$; Fig. 3). Overall, per site more extinctions than colonisations were observed $\left(\mathrm{F}_{1,36}=12.78, P=0.001\right)$.

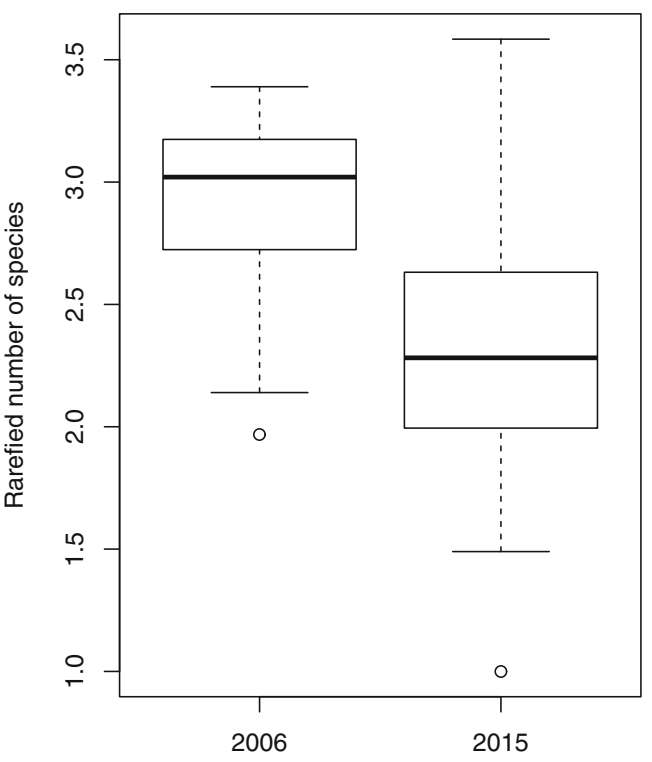

Fig. 2 Number of species per site after rarefaction \pm SE in $2006(N=16)$ (Öckinger et al. 2009) and in the present study $(N=16)$

Traditional parks had fewer colonisations compared with ruderal and semi-natural habitats $\left(\mathrm{F}_{2,16}=5.12, P=0.019\right.$; post hoc adjusted $P$-values: semi-natural versus ruderal $P=0.744$, traditional versus ruderal $P=0.018$, traditional versus seminatural $P=0.066$ ), whilst no differences in the number of extinctions were found $\left(\mathrm{F}_{2,16}=1.009, P=0.387\right.$; post hoc adjusted $P$-values: semi-natural versus ruderal $P=0.981$, traditional versus ruderal $P=0.489$, traditional versus semi-natural $P=0.395$, Fig. 4). No effects of patch area $(P=0.380)$, distance to the edge $(P=0.457)$, or proportion of green spaces $(P=0.804)$ on the number of extinctions were found when all sites were included in the model and habitat type was entered as a random factor. And similar outcomes were found when looking at colonisations (size $(P=0.132)$, distance to the edge $(P=0.900)$, and proportion of green spaces $(P=0.120))$. Finally, there were no significant effects of vegetation height, distance to the edge, or proportion of green spaces on the number of colonisations and extinctions between sites with similar characteristics (ruderal and semi-natural for vegetation height and distance to the edge; ruderal and traditional for proportion of green spaces; see Figs. 5, 6, and 7 in Online Resources).
Table 1 Observed and rarefied butterfly species richness (mean \pm SE) per management type and year

\begin{tabular}{llll}
\hline & Year & Observed species richness & Rarefied species richness \\
\hline Traditional sites & 2006 & $5.8 \pm 0.9$ & $2.6 \pm 0.6$ \\
& 2015 & $1.6 \pm 0.5$ & $1.5 \pm 0.5$ \\
Semi-natural sites & 2006 & $7.6 \pm 1.1$ & $2.8 \pm 0.2$ \\
& 2015 & $6.7 \pm 1.9$ & $2.3 \pm 0.2$ \\
Ruderal sites & 2006 & $9.5 \pm 0.6$ & $3.0 \pm 0.1$ \\
& 2015 & $8.7 \pm 1.6$ & $2.6 \pm 0.2$ \\
\hline
\end{tabular}




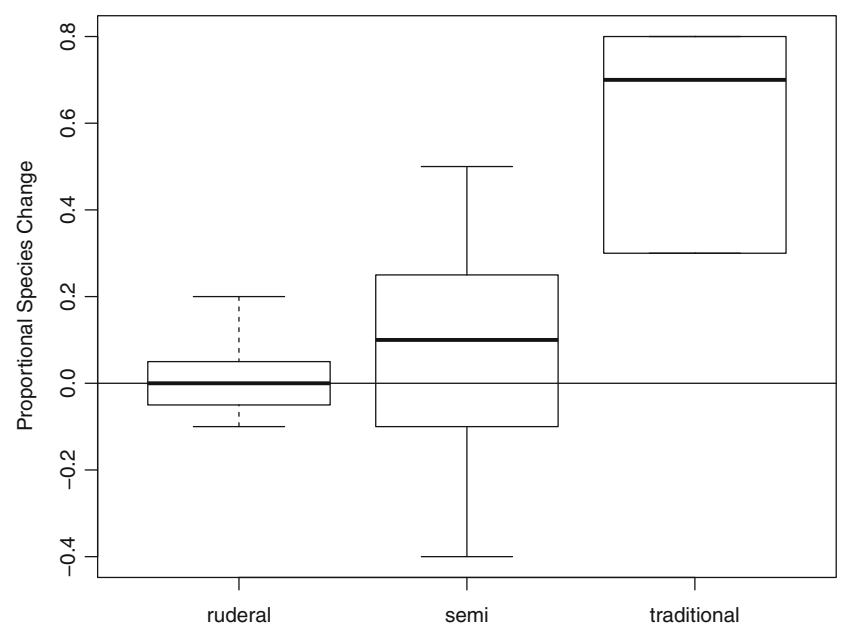

Fig. 3 Change in butterfly diversity. Y axis shows 1- Proportion of species $( \pm$ SE) from 2006 study (Öckinger et al. 2009) that were found at sites in 2015, separated into ruderal sites $(N=7)$, semi-natural sites $(N=7)$ and traditional parks $(N=5)$. The horizontal line at $\mathrm{y}=0$ shows no change

\section{Discussion}

Our study shows that local butterfly communities in urban green spaces of Malmö have become significantly simplified within a remarkably short time-period of only 9 years (2006 and 2015), even though the total number of species observed in 2015 increased by two compared with 2006. Traditional urban parks had the lowest number of species in 2015 and the greatest loss of species between 2006 and 2015, whereas semi-natural parks and ruderal sites had higher numbers of butterfly species in 2015 and also lost fewer species over time. We thus found clear differences between the three management types in their value for butterflies.

Although we acknowledge that collinearity between habitat type and landscape factors may mask effects of isolation from peri-urban and rural source populations, we argue that our findings are most likely explained by local habitat quality because of the disproportionally large declines of butterflies over time in the least favourable habitat type, in combination with the fact that none of the confounding factors by themselves explained patterns of change in butterfly assemblages over time. First, a small habitat patch size may translate into a small population size and thus with an increased risk of local extinctions (Saccheri et al. 1998). In our study, the patch sizes in each habitat category overlapped and our analyses consistently identified habitat type as the main driver of our results.

Secondly, a larger distance to the city edge could in theory decrease rescue effects from source populations in the surrounding peri-urban grasslands, independently of local habitat quality (see Öckinger et al. 2009). However, our analyses suggest that local habitat type, and not distance to the city edge, explained changes in butterfly assemblages over time, suggesting that limiting effects caused by lack of source habitats were less important than local habitat quality (Ekroos and Kuussaari 2012). Notably, several of the ruderal sites were situated in highly urbanized contexts, but still did not suffer larger losses of butterfly species than semi-natural sites, most of which in turn were situated closer to the city edge (Fig. 1).
Fig. 4 Average number of butterfly species colonisations (white) and extinctions (grey) between 2006 and 2015 per management type $\pm \mathrm{SE}$. Numbers extracted from Table 1 in Online Resources

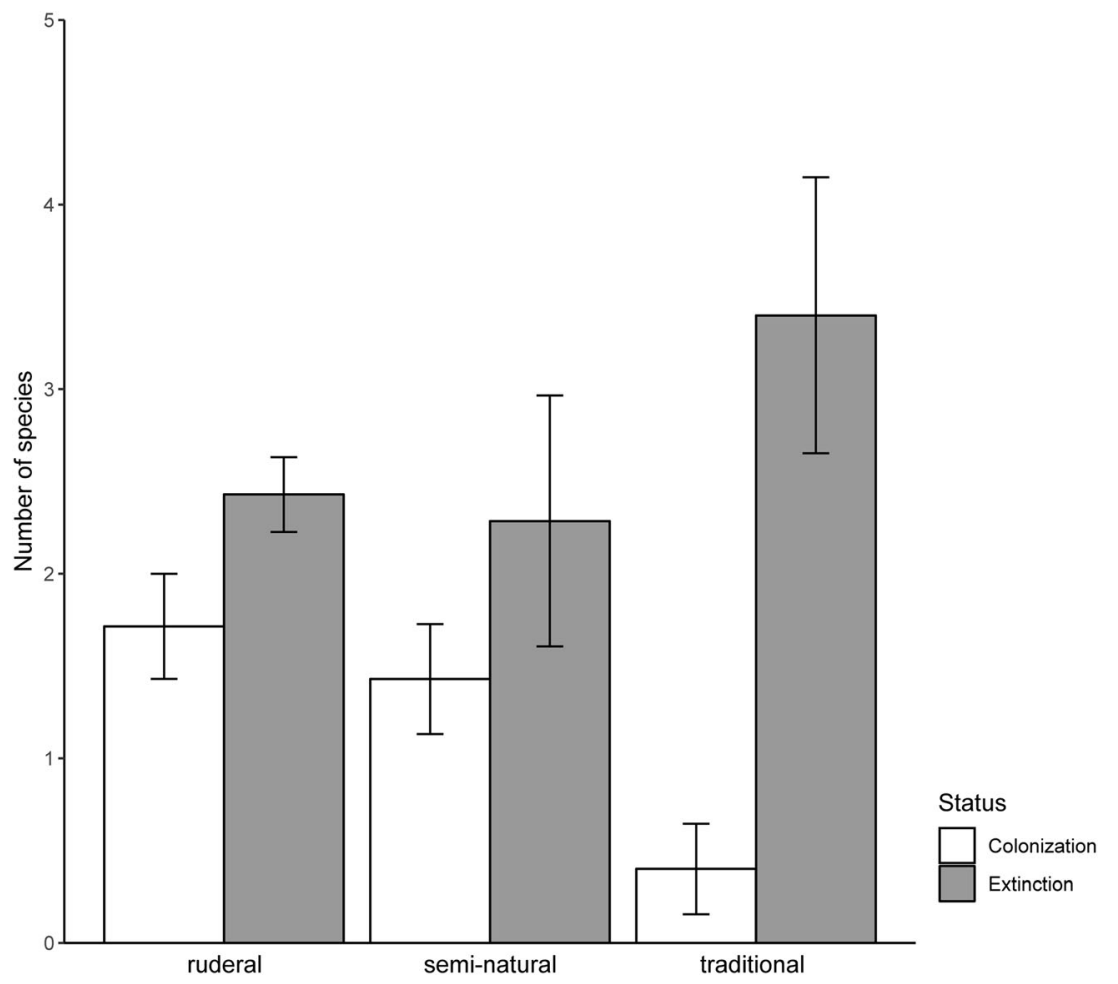


This, in combination with the relatively small spatial extent of our study area, supports the hypothesis that habitat quality inflicted by management regimes, rather than dispersal limitation or local patch size, explains the observed differences.

Butterflies are specialized herbivores that swiftly respond to changes in vegetation composition and availability of larval host plants (Thomas et al. 2004). Although adult butterflies are more opportunistic in terms of plants used as nectar sources, the ecology of larval host plants plays a fundamentally important role in the ecology of butterflies, in particular relating to local population longevity. Traditional parks were characterised by mowed lawns and in most cases high abundances of exotic species, while semi-natural and ruderal sites were either not actively managed, or mowed once or twice annually. Floral diversity is a strong predictor of butterfly host plant diversity (Fiedler 1998) and as a consequence, intensive grass cutting regimes of the traditional parks counteract the development of diverse host plant assemblages for butterflies (Öckinger et al. 2009). Our results demonstrate that ruderal sites had a consistently high butterfly diversity over time. Hence, grassland biodiversity in urban contexts benefit from retaining irregularly managed sites, which benefits plants favoured by butterflies as host or nectar sources (Collins et al. 1998; Threlfall et al. 2017).

Insect populations experience large inter-annual population fluctuations, due to e.g. weather conditions (Fourcade et al. 2017; Roy et al. 2001). The number of butterfly individuals observed in 2015 was much lower than in 2006, most likely because of a prolonged cold and rainy period in May and early June 2015. Therefore the observed difference in species richness between years could potentially be a consequence of sampling effort: as more individuals are sampled, more species will be recorded (Gotelli and Colwell 2001). However, we explicitly accounted for this effect using rarefaction techniques, and our results based on rarefied species richness consistently showed that the number of butterfly species was lower in 2015 compared with 2006.

\section{Opportunities to adapt management to benefit urban butterflies}

It might be challenging to transform traditional parks from low into high-quality sites for butterflies. Flower beds with nectar-rich flowers are attractive to highly mobile adult butterflies but not all species will benefit from such flower aggregations if native plants are missing. A relatively simple solution, while keeping the traditional park appearance, would be to plant flower beds with a diversity of native plants, offering resources both in terms of nectar sources and larval host plants (Threlfall et al. 2017). For example, Fabaceae species like Trifolium pratense and Medicago sativa are used by the larvae of Polyommatus icarus and other Lycaenidae species (Eliasson et al.
2005). Species like Succisa pratensis, Knautia arvensis, and Centaurea jacea are valuable adult nectar plants (Franzén and Nilsson 2008). All of the above are also colourful and aesthetically appealing and could be accepted as ornamentals. Adding shrubs like Frangula alnus and Rhamnus cathartica would benefit Gonepteryx rhamni and Celastrina argiolus (Eliasson et al. 2005). Another potential action is to diversify the species composition of grasses used in parks and urban green spaces, and to leave patches or sections where grass is allowed to grow tall (Ignatieva and Hedblom 2018). This would benefit skipper and satyrid larvae of e.g. Thymelicus lineola, Ochlodes sylvanus, Maniola jurtina, Coenonympha pamphilus and Aphantopus hyperantus (Eliasson et al. 2005). In addition, such actions could reduce to some extent negative impacts of the current management such as the cost, noise or pollution. Ultimately, such management regimes could improve the quality of urban green spaces not only for butterflies but also for other flowervisiting insects, such as bumblebees and hoverflies (Blackmore et al. 2014) but also for humans (Fuller et al. 2007). In fact, Malmö city is already taking steps towards more extensive management in some types of greenspace. For example, Malmö City Streets and Parks Department and the Environment Department run a project to evaluate low-intensity management regimes to some green spaces close to infrastructure (Malmö stad 2018b). In several semi-natural parks, signs have been put up to highlight local biodiversity and ecosystem functions, in order to gain acceptance from the public for such management and habitats (Malmö stad 2018c). In addition, in 2015 the Church of Sweden, which manages three large urban cemeteries in Malmö, has revised its management plans to focus more on improving cemeteries for biodiversity, e.g. through more tall grass areas (personal observation. A.S. Persson). These initiatives have the potential to promote urban biodiversity, but systematic monitoring and evaluations are needed to ascertain that these positive effects are achieved.

Most of the ruderal sites in our study were privately owned and there is a risk of losing these green spaces, especially those that can be perceived as aesthetically unappealing for the general public. Thus, despite their high value for butterflies and other insects (e.g. bees; Stenmark 2014), there are clear challenges for the municipality to coordinate a coherent and optimal management strategy for large-scale biodiversity conservation. There are also several recent and ongoing urban development projects on former industrial and harbour sites in Malmö that will lead to a general loss of ruderal habitats (Malmö stad 2018a). Hence, we see a need to acknowledge the biodiversity value of these ruderal sites in urban planning. 


\section{Conclusions}

To our knowledge, our study is among the first to analyse temporal effects of local habitat management on butterflies in an urban context. We found that traditionally and intensively managed urban green spaces cannot maintain high butterfly diversity over time, and that the general decline in species per site between 2006 and 2015 was explained by stronger declines in butterfly species richness in traditional parks, compared to ruderal and semi-natural sites. Studies on impacts of urbanization on butterflies and moths have highlighted the importance of host and food plants, heterogeneity of the urban matrix, and the quantity and quality of urban green spaces in shaping communities (Angold et al. 2006; Chong et al. 2014; Hardy and Dennis 1999; Kadlec et al. 2008; Lizée et al. 2011; Merckx et al. 2018; Öckinger et al. 2009). Additionally, it is evident that cities and urban landscapes can indeed contribute to biodiversity conservation by promoting biodiversityfriendly management strategies and maintaining heterogeneous urban landscapes (Kadlec et al. 2008; Öckinger et al. 2009). We suggest that urban butterfly diversity is to a large extent determined by composition and structure of the vegetation in urban green spaces, and we expect that relatively small changes to management intensity and design, such as promoting the establishment of particularly butterfly-friendly plant species for larvae and adults, could substantially enhance urban butterfly diversity. Furthermore, our study highlights the importance of unmanaged ruderal sites (Gutiérrez 2005; Muratet et al. 2007; Öckinger et al. 2009), commonly neglected as biodiversity-rich sites in urban planning.

Acknowledgements We thank Hristo Valchev and Sara Hellström for assistance with the field work in 2015. Ase Dannestam performed the majority of the butterfly surveys in 2006 . We gratefully acknowledge the review made by one anonymous reviewer and Thomas Merckx on an earlier version of the manuscript. EÖ received funding from the Swedish Research Council FORMAS (grant 942-2015-988). LBP received funding from the Swedish Environmental Protection Board (grant 2227-16-001).

Open Access This article is distributed under the terms of the Creative Commons Attribution 4.0 International License (http:// creativecommons.org/licenses/by/4.0/), which permits unrestricted use, distribution, and reproduction in any medium, provided you give appropriate credit to the original author(s) and the source, provide a link to the Creative Commons license, and indicate if changes were made.

\section{References}

Angold PG, Sadler JP, Hill MO, Pullin A, Rushton S, Austin K, Small E, Wood B, Wadsworth R, Sanderson R, Thompson K (2006) Biodiversity in urban habitat patches. Sci Total Environ 1360:196204. https://doi.org/10.1016/j.scitotenv.2005.08.035
Aronson MF, Lepczyk CA, Evans KL, Goddard MA, Lerman SB, MacIvor JS, Vargo T (2017) Biodiversity in the city: key challenges for urban green space management. Front Ecol Environ 15(4):189196. https://doi.org/10.1002/fee.1480

Baldock KCR, Goddard MA, Hicks DM, Kunin WE, Mitschunas N, Osgathorpe LM, Potts SG, Robertson KM, Scott AV, Stone GN, Vaughan IP, Memmott J (2015) Where is the UK's pollinator biodiversity? The importance of urban areas for flower-visiting insects. Proc R Soc Lond Biol 282:20142849. https://doi.org/10.1098/rspb. 2014.2849

Beninde J, Veith M, Hochkirch A (2015) Biodiversity in cities needs space: a meta-analysis of factors determining intra-urban biodiversity variation. Ecol Lett 18:581-592. https://doi.org/10.1111/ele. 12427

Bergerot B, Merckx T, Van Dyck H, Baguette M (2012) Habitat fragmentation impacts mobility in a common and widespread woodland butterfly: do sexes respond differently? BMC Ecol 12:5. https:// doi.org/10.1186/1472-6785-12-5

Blackmore LM, Goulson D, Stewart A, Bezemer M (2014) Evaluating the effectiveness of wildflower seed mixes for boosting floral diversity and bumblebee and hoverfly abundance in urban areas. Insect Conserv Divers 7:480-484. https://doi.org/10.1111/icad.12071

Blair RB, Launer AE (1997) Butterfly diversity and human land use: species assemblages along an urban gradient. Biol Conserv 80: 113-125. https://doi.org/10.1016/S0006-3207(96)00056-0

Chong KY, Teo S, Kurukulasuriya B, Chung YF, Rajathurai S, Tan HTW (2014) Not all green is as good: different effects of the natural and cultivated components of urban vegetation on bird and butterfly diversity. Biol Conserv 171:299-309. https://doi.org/10.1016/j. biocon.2014.01.037

Clough Y, Ekroos J, Báldi A, Batáry P, Bommarco R, Gross N, Holzschuh A, Hopfenmüller S, Knop E, Kuussaari M, Lindborg R, Marini L, Öckinger E, Potts SG, Pöyry J, Roberts SP, SteffanDewenter I, Smith HG (2014) Density of insect-pollinated grassland plants decreases with increasing surrounding land-use intensity. Ecol Lett 17:1168-1177. https://doi.org/10.1111/ele.12325

Collins SL, Knapp AK, Briggs JM, Blair JM, Steinauer EM (1998) Modulation of diversity by grazing and mowing in native tallgrass prairie. Science 280:745-747. https://doi.org/10.1126/science.280. 5364.745

Ekroos J, Kuussaari M (2012) Landscape context affects the relationship between local and landscape species richness of butterflies in seminatural habitats. Ecography 34:232-238. https://doi.org/10.1111/j. 1600-0587.2011.07005.x

Ekstam UN, Forshed N (1996) Äldre fodermarker. (Traditional Grasslands). Naturvårdsverket, Stockholm

Eliasson CU, Ryrholm N, Holmer M, Jilg K, Gärdenfors U (2005) Nationalnyckeln till Sveriges flora och fauna. Fjärilar: Dagfjärilar. Hesperiidae - Nymphalidae. SLU, Uppsala

Ferenc M, Sedláček O, Fuchs R (2014) How to improve urban greenspace for woodland birds: site and local-scale determinants of bird species richness. Urban Ecosyst 17:625-640. https://doi. org/10.1007/s11252-013-0328-x

Fiedler K (1998) Diet breadth and host plant diversity of tropical- vs. temperate-zone herbivores: south-east Asian and west Palaearctic butterflies as a case study. Ecol Entomol 23:285-297. https://doi. org/10.1046/j.1365-2311.1998.00132.x

Fourcade Y, Ranius T, Öckinger E (2017) Temperature drives abundance fluctuations, but spatial dynamics is constrained by landscape configuration: implications for climate-driven range shift in a butterfly. $\mathrm{J}$ Anim Ecol 86:1339-1351. https://doi.org/10.1111/1365-2656. 12740

Franzén M, Nilsson SG (2008) How can we preserve and restore species richness of pollinating insects on agricultural land? Ecography 31: 698-708. https://doi.org/10.1111/j.1600-0587.2008.05110.x 
Fuller RA, Irvine KN, Devine-Wright P, Warren PH, Gaston KJ (2007) Psychological benefits of greenspace increase with biodiversity. Biol Lett 3:390-394. https://doi.org/10.1098/rsbl.2007.0149

Gardiner MM, Prajzner SP, Burkman CE, Albro SL, Grewal PS (2013) Vacant land conversion to community gardens: influences on generalist arthropod predators and biocontrol services in urban greenspaces. Urban Ecosyst 17:101-122. https://doi.org/10.1007/ s11252-013-0303-6

Gotelli NJ, Colwell RK (2001) Quantifying biodiversity: procedures and pitfalls in the measurement and comparison of species richness. Ecol Lett 4:379-391. https://doi.org/10.1046/j.1461-0248.2001.00230.x

Green BH (1990) Agricultural intensification and the loss of habitat, species and amenity in British grasslands: a review of historical change and assessment of future prospects. Grass Forage Sci 45: 365-372. https://doi.org/10.1111/j.1365-2494.1990.tb01961.x

Gunnarsson B, Federsel LM (2014) Bumblebees in the city: abundance, species richness and diversity in two urban habitats. J Insect Conserv 18:1185-1191. https://doi.org/10.1007/s10841-014-9729-2

Gutiérrez D (2005) Effectiveness of existing reserves in the long-term protection of a regionally rare butterfly. ConservBiol 19:15861597. https://doi.org/10.1111/j.1523-1739.2005.00210.x

Haaland C (2017) How to preserve a butterfly species within an urbanising settlement and its surroundings: a study of the scarce copper (Lycaena virgaureae L.) in southern Sweden. J Insect Conserv 21:917-927. https://doi.org/10.1007/s10841-017-0031-y

Hall DM, Camilo GR, Tonietto RK, Ollerton J, Ahrné K, Arduser M, Ascher JS, Baldock KCR, Fowler R, Frankie G, Goulson D, Gunnarsson B, Hanley ME, Jackson JI, Langellotto G, Lowenstein D, Minor ES, Philpott SM, Potts SG, Sirohi MH, Spevak EM, Stone GN, Threlfall CG (2017) The city as a refuge for insect pollinators. Conserv Biol 31:24-29. https://doi.org/10.1111/cobi.12840

Hardy PB, Dennis RLH (1999) The impact of urban development on butterflies within a city region. Biodivers Conserv 8:1261-1279. https://doi.org/10.1023/A:100898490

Hill MJ, Biggs J, Thornhill I, Briers RA, Gledhill DG, White JC, Wood PJ, Hassall C (2017) Urban ponds as an aquatic biodiversity resource in modified landscapes. Glob Chang Biol 23:986-999. https://doi.org/10.1111/gcb.13401

Ignatieva M, Hedblom M (2018) An alternative urban green carpet. Science 362:148-149. https://doi.org/10.1126/science.aau6974

Kadlec T, Benes J, Jarosik V, Konvicka M (2008) Revisiting urban refuges: changes of butterfly and burnet fauna in Prague reserves over three decades. Landsc Urban Plan 85:1-11. https://doi.org/10.1016/ j.landurbplan.2007.07.007

Kaluza BF, Wallace H, Heard TA, Klein AM, Leonhardt SD (2016) Urban gardens promote bee foraging over natural habitats and plantations. Ecol Evol 6:1304-1316. https://doi.org/10.1002/ece3.1941

Kuussaari M, Heliölä J, Pöyry J, Saarinen K (2007) Contrasting trends of butterfly species preferring semi-natural grasslands, field margins and forest edges in northern Europe. J Insect Conserv 11:351-366. https://doi.org/10.1007/s10841-006-9052-7

Lizée MH, Manel S, Mauffrey JF, Tatoni T, Deschamps-Cottin M (2011) Matrix configuration and patch isolation influences override the species-area relationship for urban butterfly communities. Landsc Ecol 27:159-169. https://doi.org/10.1007/s10980-011-9651-x

Luoto M, Rekolainen S, Aakkula J, Pykälä J (2003) Loss of plant species richness and habitat connectivity in grasslands associated with agricultural change in Finland. AMBIO 32:447-452. https://doi.org/10. 1579/0044-7447-32.7.447

Malmö stad (2018a) Pågående översiktsplanering (eng. ongoing comprehensive planning), Stadsbyggnadskontoret, Malmö stad. Retrieved from: [https://malmo.se/Stadsplanering\%2D\%2Dtrafik/ Stadsplanering\%2D\%2Dvisioner/Oversiktsplanering\%2D\% 2Dstrategier/Pagaende-oversiktsplanering.html] date: 2018-06-13

Malmö stad (2018b) Våga vägra klippa: Miljöförvaltningen, Malmö stad. Retrieved from: [https://malmo.se/Bo-bygga\%2D\%2Dmiljo/
Miljoarbetet-i-Malmo/Malmo-stads-miljoarbete/Natur-och-miljo/ C-O-City/Vaga-vagra-klippa.html] date: 2018-06-13

Malmö stad (2018c) Kolla in naturen - Människans bästa vän Miljöförvaltningen, Malmö stad. Retrieved from: [https://malmo. se/Bo-bygga\%2D\%2Dmiljo/Miljolaget-i-Malmo/Grona-miljoer/ Ekosystemtjanster/Kolla-in-naturen-manniskans-basta-van.html] date: 2018-06-13

McKinney ML (2006) Urbanization as a major cause of biotic homogenization. Biol Conserv 127:247-260. https://doi.org/10.1016/j. biocon.2005.09.005

McKinney ML (2008) Effects of urbanization on species richness: a review of plants and animals. Urban Ecosyst 11:161-176. https:// doi.org/10.1007/s11252-007-0045-4

Merckx T, Kaiser A, Van Dyck H (2018) Increased body size along urbanization gradients at both community and intraspecific level in macro-moths. Glob Chang Biol 24:3837-3848. https://doi.org/10. $1111 /$ gcb. 14151

Moström J, Svanström S (2015) Green space and green areas within localities 2010 Statistiska Meddelanden, MI 12 SM 1501, 1-35

Muratet A, Machon N, Jiguet F, Moret J, Porcher E (2007) The role of urban structures in the distribution of wasteland flora in the greater Paris area, France. Ecosystems 10:661-671. https://doi.org/10.1007/ s10021-007-9047-6

Nilsson SG, Franzen M, Pettersson LB (2013) Land-use changes, farm management and the decline of butterflies associated with seminatural grasslands in southern Sweden. Nat Conserv 6:31-48. https://doi.org/10.3897/natureconservation.6.5205

Öckinger E, Dannestam Å, Smith HG (2009) The importance of fragmentation and habitat quality of urban grasslands for butterfly diversity. Landsc Urban Plan 93:31-37. https://doi.org/10.1016/j. landurbplan.2009.05.021

Oksanen J, Blanchet FG, Friendly M, Kindt R, Legendre P, McGlinn D, Minchin PR, O'Hara RB, Simpson GL, Solymos P, Stevens MHH, Szoecs E, Wagner H (2017) Vegan: community ecology package. R package version 2.4-5

Parris KM (2016) Ecology of urban environments. Wiley, Chichester

Persson AS, Olsson O, Rundlöf M, Smith HG (2010) Land use intensity and landscape complexity-analysis of landscape characteristics in an agricultural region in southern Sweden. Agric Ecosyst Environ 136: 169-176. https://doi.org/10.1016/j.agee.2009.12.018

Pinheiro J, Bates D, DebRoy S, Sarkar D, R Core Team (2016) nlme: linear and nonlinear mixed effects models. R package version 3.1137, https://CRAN.R-project.org/package=nlme

Pollard E, Yates TJ (1993) Monitoring butterflies for ecology and conservation. Chapman \& Hall, London

Potts SG, Biesmeijer JC, Kremen C, Neumann P, Schweiger O, Kunin WE (2010) Global pollinator declines: trends, impacts and drivers. Trends Ecol Evol 25:345-353. https://doi.org/10.1016/j.tree.2010. 01.007

R Core Team (2016) R: a language and environment for statistical computing. R Foundation for Statistical Computing, Vienna

Roy DB, Rothery P, Moss D, Pollard E, Thomas JA (2001) Butterfly numbers and weather: predicting historical trends in abundance and the future effects of climate change. J Anim Ecol 70:201-217. https://doi.org/10.1111/j.1365-2656.2001.00480.x

Saccheri I, Kuussaari M, Kankare M, Vikman P, Fortelius W, Hanski I (1998) Imbreeding and extinction in a butterfly metapopulation. Nature 392:491-494

SCB (2015) Green space and green areas within localities 2010 Statistiska meddelanden, MI 12 SM 1501. Statistics Sweden

Stenmark M (2014) Flora och fauna i järnvägsmiljöer - Sammanställning över värdefulla miljöer och hotade arter. Rapport 2014:125. Trafikverket. Swedish Transport Administration

Thomas JA (2005) Monitoring change in the abundance and distribution of insects using butterflies and other indicator groups. Philos Trans R Soc B 360:339-357. https://doi.org/10.1098/rstb.2004.1585 
Thomas JA, Telfer MG, Roy DB, Preston CD, Greenwood JJD, Asher J, Fox R, Clarke RT, Lawton JH (2004) Comparative losses of British butterflies, birds, and plants and the global extinction crisis. Science 303:1879-1881. https://doi.org/10.1126/science.1095046

Threlfall CG, Mata L, Mackie JA, Hahs AK, Stork NE, Williams NS, Livesley SJ, Beggs J (2017) Increasing biodiversity in urban green spaces through simple vegetation interventions. J Appl Ecol 54: 1874-1883. https://doi.org/10.1111/1365-2664.12876

Turrini T, Knop E (2015) A landscape ecology approach identifies important drivers of urban biodiversity. Glob Chang Biol 21:16521667. https://doi.org/10.1111/gcb.12825

Van Swaay CAM, Van Strien AJ, Aghababyan K, Åström S, Botham M, Brereton T, Carlisle B, Chambers P, Collins S, Dopagne C, Escobés R, Feldmann R, Fernández-García J. M, Fontaine B, Goloshchapova S, Gracianteparaluceta A, Harpke A, Heliölä J, Khanamirian G, Komac B, Kühn E, Lang A, Leopold P, Maes D, Mestdagh X,
Monasterio Y, Munguira M. L, Murray T, Musche M, Õunap E, Pettersson L. B, Piqueray J, Popoff S, Prokofev I, Roth T, Roy D. B, Schmucki R, Settele J, Stefanescu C, Švitra G, Teixeira SM, Tiitsaar A, Verovnik R., Warren MS (2016) The European Butterfly Indicator for Grassland species: 1990-2015. Report VS2016.019, De Vlinderstichting, Wageningen, NL: 1-42. https:// doi.org/10.13140/RG.2.2.31912.37127

Venn SJ, Kotze DJ, Lassila T, Niemelä JK (2013) Urban dry meadows provide valuable habitat for granivorous and xerophylic carabid beetles. J Insect Conserv 17:747-764. https://doi.org/10.1007/ s10841-013-9558-8

Wikström L, Milberg P, Bergman KO (2009) Monitoring of butterflies in semi-natural grasslands: diurnal variation and weather effects. J Insect Conserv 13:203-211. https://doi.org/10.1007/s10841-0089144-7 